\title{
PENERAPAN STRATEGI KONFLIK KOGNITIF UNTUK PEMBELAJARAN REMIDIASI MISKONSEPSI SISWA PADA MATERI POKOK KESETIMBANGAN KIMIA KELAS XII MIA SMA NEGERI 1 SUKOHARJO TAHUN PELAJARAN 2015/2016
}

\author{
Eko Pujianto, Mohammad Masykuri, dan Suryadi Budi Utomo \\ Program Studi Pendidikan Kimia, FKIP,Universitas Sebelas Maret, Surakarta, Indonesia \\ *Keperluan korespondensi, HP: 085799530815, e-mail: mmasykuri@yahoo.com
}

\begin{abstract}
ABSTRAK
Penelitian ini bertujuan untuk mengetahui adanya miskonsepsi pada siswa kelas XII MIA SMA Negeri 1 Sukoharjo, mengetahui penyebab miskonsepsi pada siswa tersebut, dan mengetahui pengurangan miskonsepsi setelah remediasi dengan strategi konflik kognitif pada materi pokok kesetimbangan kimia. Penelitian ini merupakan jenis penelitian deskriptif. Sampel penelitian ini diambil dengan teknik purposive sampling. Subjek penelitian ini adalah siswa kelas XII MIA 2 dan 4 SMA Negeri 1 Sukoharjo. Teknik pengumpulan data adalah instrumen Tes Pendeteksi Miskonsepsi Kimia (IPMK) yang dikembangkan oleh Das Salirawati, dan kemudian dilakukan wawancara dengan siswa yang dipengaruhi oleh miskonsepsi. Berdasarkan hasil data memberikan informasi bahwa ada miskonsepsi pada materi pokok kesetimbangan kimia untuk siswa kelas XII MIA SMA N 1 Sukoharjo. Miskonsepsi terjadi pada semua konsep dalam materi pokok kesetimbangan kimia. Konsep miskonsepsi yang paling umum adalah konsep keseimbangan dinamis dan pergeseran kesetimbangan. Miskonsepsi yang terjadi pada siswa adalah karena kondisi siswa, yang meliputi prakonsepsi salah, intuisi yang salah, penalaran tidak lengkap, dan buku pegangan siswa. Setelah belajar strategi remediasi konflik kognitif terjadi pengurangan jumlah miskonsepsi siswa.
\end{abstract}

Keta kunci: miskonsepsi, kesetimbangan kimia, penyebab miskonsepsi, remediasi, konflik kognitif

\section{PENDAHULUAN}

Pembelajaran adalah proses mengajar yang berarti membimbing dan membantu peserta didik mempermudah proses belajarnya untuk meraih kecakapan kognitif, afektif, dan psikomotor yang menyeluruh dan utuh, setahap demi setahap [1].

Kemampuan siswa dalam memahami konsep merupakan hal yang sangat penting karena konsep adalah landasan untuk berfikir [2]. Menurut Peraturan Menteri Pendidikan Nasional RI No. 22 tahun 2006, tentang Standar Isi, bahwa Standar Kompetensi dan Kompetensi Dasar mata pelajaran Kimia tingkat SMA/MA/SMALB mata pelajaran Kimia perlu diajarkan dengan tujuan untuk membekali peserta didik pengetahuan, pemahaman dan sejumlah kemampuan yang dipersyaratkan untuk memasuki jenjang pendidikan yang lebih tinggi serta mengembangkan ilmu dan teknologi. Dengan demikian informasi yang sampai ke siswa harus benar dan utuh. Kadang kala siswa tidak memasukkan konsep baru yang diajarkan kedalam jaringan konsep yang sudah ada dalam pikiran siswa. Konsep baru tersebut akhirnya berdiri sendiri dan tidak mempunyai arti, sebab arti konsep berasal dari hubungan dari konsepkonsep yang lain. Kesalahan siswa dalam pemahaman hubungan antar konsep seringkali menimbulkan miskonsepsi [3]. Miskonsepsi didefinisikan sebagai suatu gagasan yang tidak 
sesuai dengan pengertian ilmiah yang sekarang diterima [4].

Anak usia 11 sampai 18 tahun sangat memungkinkan untuk terjadinya miskonsepsi, terutama di bidang kimia. Hal ini dikarenakan oleh sifat dari ilmu kimia itu sendiri yang beberapa memang abstrak dan sulit untuk dibayangkan [5].

Derajat pemahaman siswa digolongkan menjadi enam kategori berdasarkan tes yang diberikan padanya, yaitu Pertama, tidak ada respon, dengan kriteria tidak menjawab dan/atau menjawab "saya tidak tahu". Kedua, tidak memahami, dengan kriteria mengulang pertanyaan, menjawab tetapi tidak berhubungan dengan pertanyaan dan atau jawaban tidak jelas. Ketiga, miskonsepsi, dengan kriteria menjawab tetapi penjelasannya tidak benar atau tidak logis. Keempat, memahami sebagian dan terjadi miskonsepsi, dengan kriteria jawaban menunjukkan ada konsep yang dikuasai, namun ada pernyataan yang menunjukkan miskonsepsi. Kelima, memahami sebagian, dengan kriteria jawaban menunjukkan hanya sebagian konsep yang dipahami tanpa miskonsepsi. Keenam, memahami konsep, dengan kriteria jawaban menunjukkan konsep dikuasai dengan benar [6]

Miskonsepsi kimia yang dialami siswa jelas sangat merugikan bagi kelancaran dan keberhasilan belajar mereka, apalagi jika miskonsepsi sudah terjadi lama dan tidak terdeteksi secara dini, baik oleh siswa itu sendiri maupun guru. Penelitian yang pernah dilakukan di Hungaria terhadap beberapa mahasiswa, menunjukkan bahwa mahasiswa tersebut mengalami miskonsepsi yaitu pada konsep kesetimbangan kimia [7].

Pengajaran remedial dalam proses belajar mengajar memiliki beberapa fungsi antara lain, pertama sebagai fungsi kolektif. Disini fungsi pengajaran remedial untuk memperbaiki hasil belajar melalui koreksi terhadap faktor-faktor yang terlibat dalam proses belajar. Kedua sebagai fungsi terapi, fungsi terapi ini disampinh dapat memperbaiki pemahaman siswa dalam mata pelajaran tertentu, pengajaran remedial mem- punyai fungsi memperbaiki kepribadian siswa yang diduga ada penyimpangan

Strategi konflik kognitif merupakan strategi pengubah konseptual dalam upaya mengubah miskonsepsi-miskonsepsi siswa menuju konsep yang benar [8]. Maka pada strategi konflik kognitif permasalahan akan diberikan pada kegiatan awal sebagai suatu tantangan bagi siswa untuk dapat menyelidiki dan mengekplorasi pertanyaan-pertanyaan yang diberikan guru serta pertanyaan-pertanyaan yang muncul dari struktur kognitif siswa, sehingga siswa mengetahui definisi/ pengertian, rumus, serta konsep yang lebih tepat atau lebih baik. Strategi pembelajaran konflik kognitif memberikan kesempatan kepada siswa untuk dapat berperan aktif dalam proses pembelajaran, baik dalam mencari dan menemukan sendiri informasi yang berupa konsep, teori serta kesimpulan dari suatu konsep dan teori.

Konsep yang ada dalam kesetimbangan kimia dapat dikelompokkan dalam tiga konsep, yaitu klasifikasional, korelasional, dan teoritik. Konsep yang ada di dalamnya sangat berkaitan erat dengan materi sebelumnya, seperti laju reaksi maupun stoikiometri. Adanya konsep-konsep baru yang disampaikan oleh guru dan prakonsepsi yang sudah dimiliki siswa, serta kemampuan setiap siswa yang berbeda-beda dalam menerima konsep dari guru, memungkinkan terjadinya miskonsepsi pada siswa. Miskonsepsi tersebut harus sesegara mungkin diidentifikasi dan direduksi supaya tidak semakin memberatkan siswa dalam belajar materi-materi setelahnya.

Pembelajaran menggunakan strategi konflik kognitif dapat mendorong adanya perubahan konsepsi siswa pada arah yang positif. Perubahan konsepsi siswa pada arah yang positif ini nantinya akan bermuara pada penguasaan konsep yang baik [9].

Miskonsepsi siswa yang terjadi pada materi pokok kesetimbangan kimia harus diidentifikasi sedini mungkin. Sebab-sebab yang membuat sisiwa mengalami miskonsepsi juga harus dicari. Remidiasi menggunakan strategi 
konflik kognitif menjadi suatu upaya untuk mengobati siswa yang mengalami miskonsepsi. Maka dari itu penelitian ini berjudul "Penerapan Strategi Konflik Kognitif Untuk Pembelajaran Remidiasi Miskonsepsi Siswa Kelas XII MIA SMA Negeri 1 Sukoharjo Pada Materi Pokok Kesetimbangan Kimia Tahun Pelajaran 2015/2016."

\section{METODE PENELITIAN}

Penelitian ini merupakan penelitian deskriptif yang bersifat kualitatif. Pendekatan yang digunakan oleh peneliti adalah studi kasus. Teknik untuk mengumpulkan data dalam penelitian ini meliputi tes diagnostik miskonsepsi yang disebut Instrumen Pendeteksi Miskonsepsi Kimia (IPMK) yang diadopsi dari Das Salirawati (2011), wawancara terstruktur dan analisis dokumen. Penelitian ini terdiri dari dua tahap. Tahap pertama mengidentifikasi mis- konsepsi dan tahap kedua yaitu pengurangan miskonsepsi. Penelitian ini dalaksanakan di SMA Negeri 1 Sukoharjo. Subjek penelitian ini melibatkan 71 siswa yang berada di kelas XII MIA 2 dan XII MIA 4.

\section{HASIL DAN PEMBAHASAN}

Derajat pemahaman siswa ditentukan oleh hasil jawaban siswa dalam menjawab tes IPMK (Instrumen Pendeteksi Miskonsepsi Kimia). IPMK yang digunakan adalah IPMK yang sudah dikembangakan oleh Das Salirawati.

\section{Tingkat pemahaman Siswa}

Berdasarkan hasil tes IPMK 1, diperoleh bahwa derajat pemahaman siswa untuk setiap konsep dalam pokok bahasan kesetimbangan kimia cukup beragam seperti pada tabel 1 .

Tabel 1. Derajat Pemahaman Siswa pada Setiap Konsep IPMK 1

\begin{tabular}{|c|c|c|c|c|c|}
\hline \multirow{2}{*}{$\begin{array}{c}\text { Sub Materi Pokok } \\
\text { Kesetimbangan }\end{array}$} & \multirow{2}{*}{$\begin{array}{l}\text { Indika- } \\
\text { tor }\end{array}$} & \multicolumn{4}{|c|}{ Kategori Tingkat Pemahaman (\%) } \\
\hline & & Paham & $\begin{array}{l}\text { Memahami } \\
\text { Sebagian }\end{array}$ & Miskonsepsi & $\begin{array}{l}\text { Tidak } \\
\text { Paham }\end{array}$ \\
\hline Kesetimbangan dinamis & 1 & 28,16 & 0 & 61,97 & 9,85 \\
\hline & 2 & 95,70 & 0 & 0 & 4,22 \\
\hline Rata-rata & & 61,93 & 0 & 30,98 & 7,035 \\
\hline Kesetimbangan homogeny & 3 & 97,20 & 2,82 & 0 & 0 \\
\hline dan heterogen & 4 & 95,77 & 1,41 & 1,40 & 1,40 \\
\hline Rata-rata & & 96,48 & 2,11 & 0,70 & 0,70 \\
\hline Tetapan kesetimbangan & 5 & 4,22 & 0 & 21,12 & 74,64 \\
\hline & 6 & 56,33 & 0 & 35,21 & 8,45 \\
\hline & 7 & 73,23 & 0 & 18,30 & 8,45 \\
\hline & 8 & 59,15 & 5,63 & 29,57 & 5,63 \\
\hline & 9 & 74,64 & 4,22 & 9,85 & 11,26 \\
\hline Rata-rata & & 53,52 & 1,97 & 22,81 & 21,69 \\
\hline Pergeseran Kesetimbangan & 10 & 12,67 & 2,81 & 60,56 & 23,94 \\
\hline & 11 & 40,84 & 0 & 56,33 & 2,81 \\
\hline & 12 & 50,70 & 2,81 & 39,43 & 7,04 \\
\hline Rata-rata & & 34,74 & 1,87 & 52,11 & 11,26 \\
\hline Hubungan kuantitatif antara & 13 & 60,56 & 1,41 & 26,76 & 11,26 \\
\hline komponen dalam reaksi & 14 & 71,83 & 1,41 & 25,35 & 1,40 \\
\hline kesetimbangan & 15 & 59,15 & 1,41 & 16,90 & 22,53 \\
\hline & 16 & 67,60 & 1,41 & 15,49 & 15,49 \\
\hline & 17 & 69,01 & 0 & 18,30 & 12,67 \\
\hline & 18 & 14,08 & 0 & 1,40 & 84,50 \\
\hline & 19 & 38,02 & 0 & 26,76 & 35,21 \\
\hline Rata-rata & & 54,32 & 0,80 & 18,71 & 26,15 \\
\hline $\begin{array}{l}\text { Kesetimbangan dalam } \\
\text { proses industri }\end{array}$ & 20 & 1,40 & 0 & 26,76 & 71,83 \\
\hline Rata-rata & & 1,40 & 0 & 26,76 & 71,83 \\
\hline
\end{tabular}


Keterangan tabel:

Indikator 1: Membedakan keadaan setimbang pada skala mikroskopis dan makroskopis.

Indikator 2: Menjelaskan pengertian kesetimbangan dinamis

Indikator 3: Menjelaskan pengertian homogeny dalam reaksi kesetimbangan homogen.

Indikator 4: Menentukan reaksi kesetimbangan heterogen.

Indikator 5: Menjelaskan pengertian kesetimbngan.

Indikator 6: Menjelaskan hubungan antara harga Kc dengan konsentrasi reaktan dan produk.

Indikator 7: Meramalkan konsentrasi zat yang terlibat dalam reaksi kesetimbangan.

Indikator 8: $\quad$ Menentukan harga Kc berdasarkan data empiris.

Indikator 9: Menentukan harga Kc dari reaksi kesetimbangan heterogen.

Indikator 10: Menentukan arah pergeseran kesetimbangan akibat perubahan tekanan.

Indikator 11: Menjelaskan arah pergeseran kesetimbangan akibat perubahan konsentrasi salah satu zat.

Indikator 12: Menjelaskan peranan katalis dalam reaksi kesetimbangan kimia.

Indikator 13: Mengitung harga Kc jika diketahui jumlah mol mula-mula

Indikator 14: Menghitung harga Kp jika diketahui jumlah mol zay-zat yang terlibat dalam reaksi.

Indikator 15: Menghitung harga Kc jika diketahui jumlah mol reaktan pada keadaan setimbang.

Indikator 16: Menghitung harga Kp berdasarkan hubungannya dengan harga Kc untuk kesetimbangan homogeny gas.

Indikator 17: Menjelaskan hubungan harga Kc dengan a pada suatu reaksi kesetimbangan.

Indikator 18: Menentukan jumlah mol mula-mula dalam kesetimbangan jika harga a diketahui.

Indikator 19: Menghitung jumlah mol zat yang terurai jika diketahui jumlah harga mol zat-zat pada keadaan setimbang.

Indikator 20: Menjelaskan manfaat reaksi kesetimbangan dalam proses industry.

Siswa mengalami miskonsepsi paling banyak pada butir soal nomor 1 , 10, dan 11. Indikator pembelajaran pada butir soal nomor 1 adalah siswa dapat membedakan dengan tepat keadaan setimbang pada skala mikroskopis dan makroskopis, indikator soal nomor 10 adalah siswa mampu menentukan arah pergeseran kesetimbangan akibat perubahan tekanan dengan benar, dan indikator butir soal nomor 11 siswa mampu menjelaskan arah pergeseran kesetimbangan akibat perubahan konsentrasi salah satu zat dengan benar. Jika dihitung dalam rata-rata persentase miskonsepsi sub materi kesetimbangan kimia, siswa paling banyak mengalami miskonsepsi pada konsep kesetimbangan dinamis miskonsepsi sebanyak
$30,98 \%$, dan konsep pergeseran kesetimbangan miskonsepsi sebanyak $52,10 \%$.

Setelah dilakukan pembelajaran remedial menggunakan strategi konflik kognitif, siswa kemudian diminta mengerjakan tes IPMK 2. Berdasarkan data hasil tes IPMK 2, diperoleh bahwa derajat pemahaman siswa setiap konsep dalam pokok bahasan kesetimbangan kimia seperti yang ditunjukkan oleh Tabel 2. Dapat diketahui bahwa siswa masih mengalami miskonsepsi pada konsep kesetimbangan dinamis indikator 1 dengan persentase miskonsepsi $21,21 \%$. Pada konsep pergeseran kesetimbangan indikator 10, 11 dan 12 dengan prosentase $26,76 \% ; 1,40 \%$ dan $22,53 \%$. 
Tabel 2. Derajat Pemahaman Siswa pada Setiap Konsep IPMK 2

\begin{tabular}{|c|c|c|c|c|c|}
\hline \multirow{2}{*}{$\begin{array}{l}\text { Sub Materi Pokok } \\
\text { Kesetimbangan }\end{array}$} & \multirow{2}{*}{$\begin{array}{l}\text { Indika- } \\
\text { tor }\end{array}$} & \multicolumn{4}{|c|}{ Kategori Tingkat Pemahaman (\%) } \\
\hline & & Paham & $\begin{array}{l}\text { Memahami } \\
\text { Sebagian }\end{array}$ & Miskonsepsi & $\begin{array}{l}\text { Tidak } \\
\text { Paham }\end{array}$ \\
\hline \multirow{2}{*}{ Kesetimbangan dinamis } & 1 & 52,11 & 0 & 21,12 & 26,76 \\
\hline & 2 & 67,60 & 0 & 0 & 32,39 \\
\hline Rata-rata & & 5986 & 0 & 10,56 & 29,58 \\
\hline Kesetimbangan homogen & 3 & 95,77 & 2,81 & 0 & 1,41 \\
\hline dan heterogen & 4 & 40,84 & 1,40 & 39,43 & 18,30 \\
\hline Rata-rata & & 68,31 & 2,11 & 19,72 & 9,86 \\
\hline \multirow{5}{*}{ Tetapan kesetimbangan } & 5 & 94,36 & 1,40 & 1,40 & 2,81 \\
\hline & 6 & 7,04 & 0 & 19,71 & 73,23 \\
\hline & 7 & 59,15 & 0 & 33,80 & 7,04 \\
\hline & 8 & 71,83 & 0 & 19,71 & 8,45 \\
\hline & 9 & 77,46 & 1,40 & 15,49 & 5,63 \\
\hline Rata-rata & & 61,97 & 0,56 & 18,03 & 19,44 \\
\hline \multirow{3}{*}{ Pergeseran Kesetimbangan } & 10 & 60,56 & 0 & 26,76 & 12,67 \\
\hline & 11 & 94,36 & 0 & 1,40 & 4,22 \\
\hline & 12 & 66,19 & 0 & 22,53 & 1,40 \\
\hline Rata-rata & & 76,53 & 0 & 16,90 & 6,10 \\
\hline Hubungan kuantitatif antara & 13 & 61,97 & 4,22 & 28,16 & 5,63 \\
\hline komponen dalam reaksi & 14 & 78,87 & 2,81 & 5,63 & 12,67 \\
\hline \multirow[t]{5}{*}{ kesetimbangan } & 15 & 39,43 & 1,40 & 32,25 & 26,76 \\
\hline & 16 & 56,33 & 2,81 & 30,98 & 9,85 \\
\hline & 17 & 70,42 & 1,40 & 14,08 & 14,08 \\
\hline & 18 & 69,01 & 0 & 18,30 & 12,67 \\
\hline & 19 & 18,30 & 0 & 1,40 & 80,28 \\
\hline Rata-rata & & 56,34 & 1,81 & 18,71 & 23,14 \\
\hline $\begin{array}{l}\text { Kesetimbangan dalam } \\
\text { proses industri }\end{array}$ & 20 & 71,83 & 1,40 & 18,30 & 8,45 \\
\hline Rata-rata & & 71,83 & 1,40 & 18,30 & 8,45 \\
\hline
\end{tabular}

\section{Hasil Wawancara}

Dalam penelitian ini, dilakukan wawancara terstruktur dan mendalam dengan mengambil empat responden dari seluruh siswa yang mengalami miskonsepsi pada materi pokok kesetimbangan kimia. Dari hasil wawancara akan diketahui bentukbentuk miskonsepsi yang terjadi pada siswa dan sebab-sebab terjadinya miskonsepsi.

Responden wawancara 1 menunjukkan bahwa siswa sudah paham maksud pertanyaan dari setiap soal dan sudah bisa memilah hal-hal yang diketahui dari soal, akan tetapi terkadang siswa kurang teliti. Misalnya pada soal nomor 16 penentuan Kc yang sudah paham tetapi pemilihan jawabannya kurang di teliti lagi. Misalnya lagi pada nomor 13 menghitung tetapan kesetimbangan (Kc) dari suatu reaksi subjek sudah memahami rumus dan langkah- langkah pengerjaannya tetapai belum begitu memahami antara konsentrasi dan mol, tanpa mencermati pilihan alasan yang ada. Subjek kebanyakan memahami konsep secara tidak utuh. Pada nomor 12 juga mengalami miskonsepsi, subjek sudah memahami fungsi katalis tetapi tidak bisa menjelaskan secara rinci, siswa yang mengalami miskonsepsi rata-rata menjawab bahwa katalis dapat mempercepat reaksi karena harga Kc bertambah, walaupun sebenarnya nila Kc bertambah tetapi bukan karena itu katalis mempercepat reaksi. Pada nomor 17 siswa juga mengalami miskonsepsi, siswa hanya cenderung menghafalkan rumus tetapi kurang memahami dan kurang teliti dalam menerapkannya dalam soal. Subjek 1 rata-rata mengalami miskonsepsi pada konsep hubungan kuantitatif antara pereaksi 
dengan hasil reaksi dari suatu reaksi kesetimbangan.

Responden wawancara 2 menunjukkan bahwa ia mengalami miskonsepsi hampir disemua butir soal. Pengerjaannya sering tergesa-gesa dan pemahamannya yang tidak utuh sehingga menyebabkan miskonsepsi. Pada Kesetimbangan dinamis, yang siswa pahami adalah konsentrasi reaktan sama dengan konsentrasi produk tetapi reaksi tetap berangsung secara mikroskopis. Siswa belajar secara tekstual dibuku dan hanya hanya mendapat konsep bahwa reaksi kesetimbangan dinamis secara makroskopis diam dan secara mikroskopis tetap berlangsung dengan tidak memperhatikan konsentrasi reaktan maupun produk. Sedangkan pada konsep kesetimbangan homogen dan heterogen tidak mengalami miskonsepsi. Pada konsep tetapan kesetimbangan siswa hanya cenderung menghafalkan rumus yang ada di buku dan yang diajarkan oleh guru saja. Kemudian dalam menghitung soal kesetimbangan, siswa juga kurang memahami antara melibatkan mol atau molaritas zat. Pada konsep kesetimbangan kimia siswa mengalami miskonsepsi paling banyak. Siswa dengan yakin menjawab, misal nomor 10 reaksi :

$$
\mathrm{Fe}^{3+}(\mathrm{aq})+\mathrm{SCN}^{-}(\mathrm{aq}) \rightleftharpoons \mathrm{FeSCN}^{2+}(\mathrm{aq})
$$

Ketika ditambah larutan $\mathrm{FeCl}_{3}$ pada suhu tetap siswa kebanyakan menjawab tidak mempengaruhi kesetimbangan, dengan alasan $\mathrm{Fe}^{3+}$ bertambah dan ion SCN' tetap. Pada soal nomor 11 siswa masih miskonsepsi dalam pelibatan koefisien reaksi. Pada konsep hubungan kuantitatif antar komponen dalam reaksi kesetimbangan, sama seperti subjek 1 yaitu belum bisa membedakan konsep antara mol dan molaritas seperti nomor 13,14 , dan 15 . Ada soal yang tidak dijawab karena kurang yakinnya dengan konsep yang siswa miliki.

Responden wawancara 3 menunjukkan bahwa ia dapat memahami maksud dari setiap soal, dapat memilah hal-hal yang diketahui dalam soal, akan tetapi ia mengalami miskonsepsi pada soal tetapan kesetimbangan. Hal ini ditunjukkan ketika siswa diberikan soal yang sama, saat mengerjakan kembali soal yang sama, ia menjawab hanya terpaku pada rumus. Misalnya pada nomor butir soal 5 , siswa menjawab dengan hanya menghafal rumus bahwa tetapan kesetimbangan adalah produk di bagi dengan reaktan dipangkatkan koefisiennya. la juga mengalami miskonsepsi karena penguasaan konsep yang tidak utuh.

Responden wawancara 4 menunjukkan bahwa ia memahami soal yang diberikan, akan tetapi ia kurang teliti dalam mengerjakanya. Selain itu, siswa juga menyatakan bahwa ada cukup banyak soal yang ia jawab dengan menebak. Siswa bingung pada pilihan alasan yang diberikan. Sebenarnya siswa sudah cukup yakin dalam memilih jawaban pertanyaan, akan tetapi ia bingung dengan pilihan alasan yang ada, sehingga ia memilih alasan jawaban dengan cara menebaknya, yaitu dengan cara mengambil kemungkinan alasan yang paling mendekati atau paling berkaitan dengan jawaban soal. Pada soal kesetimbangan dinamis, menurut siswa dalam kesetimbangan dinamis konsentrasi produk dan reaktan tetap walaupun alasannya sudah benar yaitu secara mikroskopis reaksi tetap berlangsung. Siswa menjawab demikian karena tidak begitu mendalami konsep dan hanya berpaku pada pengertian yang ada du buku ataupun yang diajarkan guru. Selain itu, pada soal yang berupa hitungan reaksi kesetimbangan, siswa sudah paham konsep dan cukup teliti dalam mengerjakan soal.

\section{Temuan Miskonsepsi Materi Kesetimbangan Kimia}

Siswa mengalami miskonsepsi hampir di setiap indikator pembelajaran kesetimbangan kimia. Berdasarkan hasil tes IPMK 1 yang telah dilakukan diketahui bahwa hanya ada 2 butir soal atau indikator pembelajaran dimana siswa tidak mengalami miskonsepsi. Beberapa temuan miskonsepsi seperti pada tabel 3 . 
Tabel.3 Temuan Miskonsepsi pada Materi Kesetimbangan Kimia

\begin{tabular}{|c|c|c|}
\hline $\begin{array}{l}\text { Sub Materi } \\
\text { Pokok }\end{array}$ & Konsep & Temuan Miskonsepsi \\
\hline $\begin{array}{l}\text { Kesetimbangan } \\
\text { dinamis }\end{array}$ & $\begin{array}{l}\text { a. Pada reaksi kesetimbangan, } \\
\text { konsentrasi rekatan dan produk } \\
\text { tidak sama melainkan laju } \\
\text { rekasinya yang sama. } \\
\text { b. Konsetrasi zat dalam reaksi } \\
\text { kesetimbangan baik reaktan } \\
\text { maupun produk secara } \\
\text { mikroskopisnselalu berubah- } \\
\text { ubah sesuai dengan proses } \\
\text { yang berlangsung. }\end{array}$ & $\begin{array}{l}\text { a. Siswa memahami pada reaksi } \\
\text { kesetimbangan konsentrasi } \\
\text { produk dan reaktannya sama. } \\
\text { b. Konsentrasi zat baik reaktan } \\
\text { maupun produk tidak terjadi } \\
\text { perubahan atau tetap ketika } \\
\text { tercapai kesetimbangan }\end{array}$ \\
\hline $\begin{array}{l}\text { Kesetimbangan } \\
\text { homogen dan } \\
\text { heterogen }\end{array}$ & $\begin{array}{l}\text { Reaksi kesetimbangan heterogen } \\
\text { yaitu reaksi kesetimbangan dimana } \\
\text { rekatan dan produk yang terlibat } \\
\text { dalam reaksi memiliki fase yang } \\
\text { berbeda, dan antar reaktan saling } \\
\text { bereaksi }\end{array}$ & $\begin{array}{l}\text { Kesetimbangan heterogen adalah } \\
\text { reaksi kesetimbangan yang } \\
\text { melibatkan zat yang berbeda }\end{array}$ \\
\hline $\begin{array}{l}\text { Tetapan } \\
\text { kesetimbangan }\end{array}$ & $\begin{array}{l}\text { a. Harga tetapan kesetimbangan } \\
\text { berdasarkan konsentrasi (Kc) } \\
\text { menyatakan perbandingan } \\
\text { konsentrasi antara produk dibagi } \\
\text { reaktan dipangkatkan sesuai } \\
\text { angka koefisien masing-masing } \\
\text { zat yang memiliki fase aquos } \\
\text { (aq) dan gas (g) }\end{array}$ & $\begin{array}{l}\text { a. Tetapan kesetimbangan } \\
\text { merupakan besaran yang } \\
\text { menyatakan perbandingan } \\
\text { produk dibagi reaktan tanpa } \\
\text { memperhatikan fasenya }\end{array}$ \\
\hline \multirow{6}{*}{$\begin{array}{l}\text { Pergeseran } \\
\text { kesetimbangan }\end{array}$} & $\begin{array}{l}\text { b. Dengan melihat harga tetapan } \\
\text { kesetimbangan dapat ditentukan } \\
\text { komposisi reaktan dan produk }\end{array}$ & $\begin{array}{l}\text { b. Karena siswa hanya } \\
\text { menghafalkan rumus } \\
\text { menentukan harga tetapan } \\
\text { kesetimbangan (Kc) saja maka } \\
\text { siswa menjawab dengan } \\
\text { meilihat Kc dapat ditentukan } \\
\text { angka koefisien dari zat-zat } \\
\text { yang terlibat dalam reaksi }\end{array}$ \\
\hline & $\begin{array}{l}\text { c. Kurung siku, [] dalam rumus Kc } \\
\text { menunjukkan konsentrasi yang } \\
\text { dinyatakan dalam mol per liter }\end{array}$ & $\begin{array}{l}\text { c. Kurung siku, [ ] dalam rumus } \\
\text { Kc menunjukkan jumlah mol } \\
\text { zat }\end{array}$ \\
\hline & $\begin{array}{l}\text { a. Pada reaksi kesetimbangan, } \\
\text { fase zat-zat yang terlibat reaksi } \\
\text { harus diperhatikan }\end{array}$ & $\begin{array}{l}\text { a. Pada reaksi kesetimbangan, } \\
\text { fase zat-zat yang terlibat reaksi } \\
\text { tidak diperhatikan }\end{array}$ \\
\hline & $\begin{array}{lr}\text { b. Pengaruh } & \text { pergeseran } \\
\text { kesetimbangan } & \text { akibat }\end{array}$ & $\begin{array}{lr}\text { b. Pengaruh } & \text { pergeseran } \\
\text { kesetimbangan } & \text { akibat }\end{array}$ \\
\hline & $\begin{array}{l}\text { penambahan konsentrasi zat } \\
\text { berhubungan dengan jumlah } \\
\text { koefisien dari zat-zat rekasi } \\
\text { antara produk dan rekatan }\end{array}$ & $\begin{array}{l}\text { penambahan konsentrasi zat } \\
\text { berhubungan dengan koefisien } \\
\text { masing-masing zat (tidak } \\
\text { dijumlahkan) antara reaktan } \\
\text { dan produk }\end{array}$ \\
\hline & $\begin{array}{ll}\text { c. Katalis dapat } & \text { memepercepat } \\
\text { tercapainya } & \text { kesetimbangan } \\
\text { dengan cara menurunkan (Ea) }\end{array}$ & $\begin{array}{l}\text { c. Katalis dapat memepercepat } \\
\text { tercapainya kesetimbangan } \\
\text { dengan cara memperbesar } \\
\text { harga K }\end{array}$ \\
\hline \multirow{2}{*}{$\begin{array}{l}\text { Hubungan } \\
\text { kuantitatif antar } \\
\text { komponen } \\
\text { dalam reaksi } \\
\text { kesetimbangan }\end{array}$} & $\begin{array}{l}\text { a. Kurung siku, [ ] dalam rumus Kc } \\
\text { menunjukkan konsentrasi yang } \\
\text { dinyatakan dalam mol per liter }\end{array}$ & $\begin{array}{l}\text { a. Kurung siku, [ ] dalam rumus } \\
\text { Kc menunjukkan jumlah mol } \\
\text { zat }\end{array}$ \\
\hline & $\begin{array}{l}\text { b. harga } \mathrm{Kp} \text { dapat dihitung } \\
\text { berdasarkan perbandingan } \\
\text { tekanan parsial produk dibagi }\end{array}$ & $\begin{array}{l}\text { b. Siswa meganggap bahwa } \\
\text { mencari } \\
\text { kesetimbangan tekanan (Kp) }\end{array}$ \\
\hline
\end{tabular}






\section{Perbandingan jumlah miskonsepsi}

Dari hasil tes IPMK 1 diketahui bahwa siswa mengalami miskonsepsi paling banyak pada sub materi kesetimbangan kimia dengan persentase miskonsepsi 30,96\%, dan konsep pergeseran kesetimbnagan dengan ratarata persentase $52,10 \%$. Setelah siswa diberikan pembelajaran remidiasi menggunakan strategi konflik kognitif, jumlah siswa miskonsepsi mengalami penurunan. Miskonsepsi pada konsep kesetimbangan dinamis menjadi sebanyak 21,21\%. Pada konsep pergeseran kesetimbangan ratarata persentase $16,90 \%$.

\section{Penyebab Miskonsepsi}

Dari hasil wawancara dengan siswa miskonsepsi ditemukan beberapa faktor yang menjadi penyebab miskonsepsi. Diantaranya adalah kondisi siswa yang berupa prakonsepsi atau konsep awal yang tidak tepat, intuisi yang salah, siswa mengalami penalaran yang salah dan istilah-istilah dalam buku pelajaran yang digunakan oleh siswa.

Berdasarkan hasil identifikasi miskonsepsi [10] dan survei nasional yang dilakukan oleh Mei-Hung Chiu di Taiwan pada tahun 2000 sampai 2003 mengenai konsepsi kimia di Taiwan, menunjukkan bahwa miskonsepsi yang terjadi pada siswa SMP dan SMA atau tingkat atas terutama disebabkan oleh buku ajar [11]

\section{KESIMPULAN}

Berdasarkan analisis data yang diperoleh, maka dapat ditarik kesimpulan bahwa terjadi miskonsepsi pada materi kesetimbangan kimia, sub materi pokok kesetimbangan dinamis sebesar $30,97 \%$; kesetimbangan homogen dan heterogen sebanyak $1,41 \%$; tetapan kesetimbangan sebanyak 22,82\%; pergeseran kesetimbangan sebanyak $52,10 \%$; hubungan kuantitatif antara komponen dalam reaksi kesetimbangan sebanyak $18,71 \%$ dan kesetimbangan dalam proses industri sebanyak $26,76 \%$ pada siswa kelas XII MIA SMA Negeri 1 Sukoharjo tahun ajaran 2015/2016. Penyebab terjadinya miskonsepsi siswa adalah kondisi siswa, yang meliputi prakonsepsi yang salah, intuisi yang salah, reasoning yang tidak lengkap, dan buku pegangan siswa. Setelah dilakukan pembelajaran remidiasi menggunakan strategi konflik kognitif terjadi pengurangan jumlah siswa miskonsepsi pada sub materi pokok kesetimbangan dinamis sebesar $32,95 \%$ dan pergeseran kesetimbangan sebesar $65,39 \%$

\section{UCAPAN TERIMA KASIH}

Penulis mengucapkan terima kasih kepada Bapak Drs. Darno, selaku Kepala Sekolah yang telah memberikan izin penelitian di SMA Negeri 1 Sukoharjo, Edi Santoso, M.Pd. dan Ibu Perihatmi, 
S.Pd. selaku Guru Mata Pelajaran Kimia yang telah meluangkan waktu dan membantu jalan penelitian hingga dapat terselesaikannya penelitian ini.

\section{DAFTAR RUJUKAN}

[1] Syah, M. 2008. Psikologi Pendidikan dengan Pendekatan Baru. Bandung: Remaja Rosdakarya.

[2] Dahar, R. W. 1996. Teori-Teori Belajar. Jakarta: Erlangga

[3] Berg, E. V. 1991. Miskonsepsi Fisika dan Remediasi. Salatiga: Universitas Satya Wacana.

[4] Shen, M. M. 2013. Miskonsepsi dalam Pembelajaran di Sekolah. Diperoleh dari http://lpmpntb.org/serba_serbi.php?/ 50/miskonsepsi_dalam_pembelajar andi_sekolah. Diakses 7 Maret 2015.

[5] Barker, V. 2004. Students misconceptions about basic chemicall ideas science and technology Group Institute of Education, Universityof London Tersedia $d i$ http://www.rsc.org/education/teache rs/learnnet/pdf/LearnNet/rsc/micson .pdf. Diakses tanggal 1 maret 2015.

[6] Salirawati, Penelitian D. 2011., Jurnal Pendidikan,15 (2), 232-249.

[7] Kolomuç, A. \& Tekin, S. 2011., Eurasian J. Phys. Chem. Educ, 03 (2): 84-101

[8] Sadia, I W. 1997. Efektifitas Strategi Konflik Kognitif Dalam Mengubah Miskonsepsi Siswa (Suatu Studi Kuasi Eksperimental Dalam Pembelajaran Konsep Energi, Usaha, Dan Gaya di SMU N 1 Singaraja). Laporan penelitian (tidak diterbitkan). Singaraja: STKIP Singaraja.
[9] Baser, M. 2006., Eurasia Journal of Mathematics, Science and Technology Education, 2 (2), 108

[10] Astuti, F. dkk. 2015., Jurnal Pendidikan Kimia , 5 (2), 99-102

[11] Chiu, M. 2007, International Journal of Science Education., 29 (4), 421 452. 